\title{
Neurogenic thoracic outlet syndrome
}

INSERM

\section{Source}

INSERM. (1999). Orphanet: an online rare disease and orphan drug data base.

Neurogenic thoracic outlet syndrome. ORPHA:100073

Neurogenic thoracic outlet syndrome (NTOS) is a form of thoracic outlet syndrome

(TOS; see this term) that presents with pain, paresthesias and weakness in an upper extremity and is divided into true NTOS and disputed NTOS. 